\title{
Current data on the characterization of oral clefts in Brazil
}

\section{Informações atuais sobre a caracterização das fissuras orofaciais no Brasil}

\author{
José Alberto de Souza Freitas* \\ Gisele da Silva Dalben** \\ Milton Santamaria Júnior*** \\ Patrícia Zambonato Freitas****
}

\begin{abstract}
This study aimed at investigating the current distribution of the several types of clefts among the patients receiving treatment at the Hospital for Rehabilitation of Craniofacial Anomalies (HRAC-USP), Bauru, Brazil, for the first time during the year 2000. A total of 803 unoperated patients with cleft lip and/or palate, with or without additional malformations, with no recognizable syndromes, who came to the HRAC-USP for enrollment for treatment during the year 2000. A predominance of complete cleft lip and palate, either unilateral or bilateral, was observed $(37.1 \%)$, followed by isolated cleft palate $(31.7 \%)$ and isolated cleft lip $(28.4 \%)$. A discrete relationship between cleft palate and the female gender was noticed (53\%), and males were more affected by the other types of clefts (around 60\%). The findings revealed a predominance of complete clefts of the primary and secondary palate, the treatment of which is more complex, and whose frequency is greater in males.
\end{abstract}

DESCRIPTORS: Cleft lip; Cleft palate; Epidemiology.

\begin{abstract}
RESUMO: Foi objetivo do presente estudo investigar a distribuição atual dos vários tipos de fissuras entre pacientes que compareceram ao Hospital de Reabilitação de Anomalias Craniofaciais (HRAC-USP), Bauru, Brasil, pela primeira vez, no ano de 2000. No total, 803 pacientes não operados com fissura de lábio e/ou palato, com ou sem malformações adicionais, sem síndromes reconheciveis, compareceram ao HRAC-USP para inscrição para tratamento durante o ano de 2000. Foi observada predominância de fissura completa de lábio e palato, unilateral ou bilateral $(37,1 \%)$, seguida pela fissura de palato isolada $(31,7 \%)$ e fissura de lábio isolada $(28,4 \%)$. Foi notada uma relação discreta entre a fissura de palato e o gênero feminino (53\%), sendo o gênero masculino mais afetado pelos outros tipos de fissuras (cerca de 60\%). Os achados revelaram uma predominância de fissuras completas do palato primário e secundário, cujo tratamento é mais complexo, e uma maior ocorrência no gênero masculino.
\end{abstract}

DESCRITORES: Fenda labial; Fissura palatina; Epidemiologia.

\section{INTRODUCTION}

Each type of oral cleft demands a specific protocol for rehabilitation, especially those clefts that involve the alveolar ridge, which usually require bone grafting procedures to allow proper orthodontic finalization without the limiting bone defect. A number of studies were carried out to investigate the distribution of the several types of clefts and the relationship of these clefts with characteristics such as gender, race and socioeconomical background.

Regarding the type of cleft, a number of authors have observed that cleft lip and palate is more frequent than the isolated cleft lip and isolated cleft palate ${ }^{3-8,10,12,16,17,19}$. Nevertheless, there were also scarce findings of higher frequencies of isolated cleft palate ${ }^{1,2,18}$ and isolated cleft lip ${ }^{15}$ in relation to the other types of clefts.

Most studies have indicated higher rates of unilateral clefts compared to bilateral, as the left side is the most commonly affected by clefting ${ }^{2-}$ $7,9,14-18$

In relation to the association between clefting and gender, a worldwide trend has been observed towards higher rates of isolated cleft palate among females and higher frequencies of cleft lip with or without cleft palate in males ${ }^{2-7,10,12,14-18}$.

Some authors have also made an attempt to observe a possible relationship between race and type of cleft. Many studies revealed a higher frequency of clefts among caucasian patients in

* PhD in Oral Radiology, Superintendent; **Master Student in Orofacial Clefts; ***MSc in Orthodontics - Hospital for Rehabili-

tation of Craniofacial Anomalies, University of São Paulo.

*** Master Student in Orthodontics, School of Dentistry, Federal University of Rio de Janeiro. 
Freitas JAS, Dalben GS, Santamaria Júnior M, Freitas PZ. Current data on the characterization of oral clefts in Brazil. Braz Oral Res 2004;18(2):128-33.

relation to individuals of African descent ${ }^{6,13,14,19}$. A trend towards higher rates of clefts among populations of Asian descent in relation to all other races has also been found ${ }^{14}$. Some authors also stated that a relationship between race and clefting could not be found 5 .

The Hospital for Rehabilitation of Craniofacial Anomalies of the University of São Paulo (HRACUSP), located in Bauru, Brazil and established in 1967, has assisted more than 37,000 patients presenting craniofacial malformations, especially cleft lip and palate, providing a mean of 2,300 ambulatory treatments every month. This allows the development of research comprising large numbers of subjects. For that purpose, this study was designed to investigate the current distribution of the several types of clefts among the patients receiving treatment at the HRAC-USP for the first time during the year 2000 .

\section{MATERIAL AND METHODS}

A total of 803 consecutive patients seen at the diagnosis sector of the Hospital for Rehabilitation of Craniofacial Anomalies (HRAC-USP), in Bauru, Brazil, during the year 2000 were included in this study. Examination included evaluation of the type of cleft and its extension to determine the anatomical structures affected by the cleft. A graphic representation was included in the record of each patient (Figure 1). Personal information such as race, gender, age and area of residence were also recorded. All patients and/or caretakers received information on the objectives of the study and signed an informed consent form complying for participation in the study.

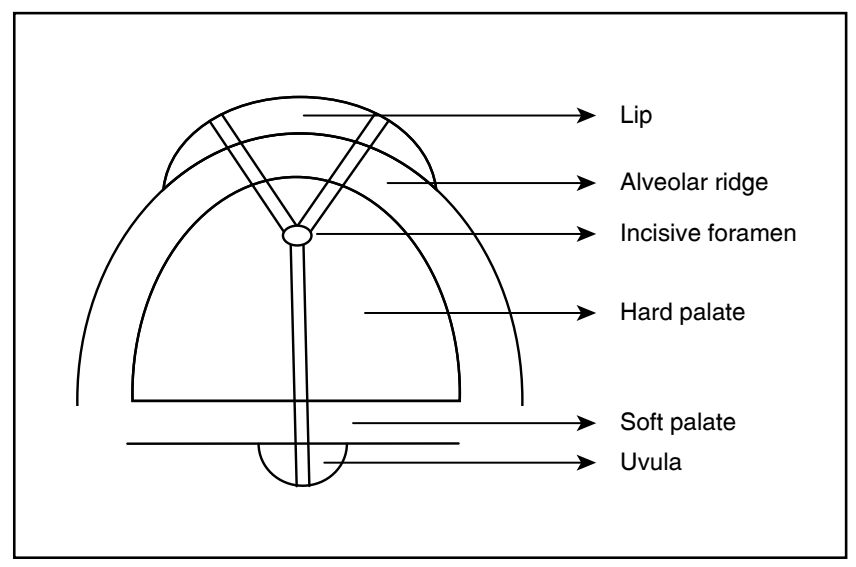

FIGURE 1 - Diagrammatic scheme for graphic representation of the cleft lip and palate.
Patients who had already undergone any kind of surgical procedure for correction of the cleft were excluded from the study, in order to avoid misclassification of the type of cleft. Patients with recognizable syndromes were also excluded, except for patients with median cleft lip or median cleft lip and palate, which are very rare and usually occur together with some syndromes.

All clefts were characterized as precisely as possible and classified as complete or incomplete and unilateral or bilateral, in order to gather proper information on the extent and severity of the anomaly. Associations of clefts were described in detail.

After data collection, descriptive statistical analysis was carried out to determine percentages and means, as well as possible relationships between the variables included in the study.

The Ethics Committee of the HRAC-USP reviewed and approved the present study before its onset.

\section{RESULTS}

The mean age of the patients was 2.8 years, ranging from 6 days to 49 years. The male gender was predominant in the total sample (55\%). More than $80 \%$ of the patients were caucasians or noncaucasian whites, including admixture between whites and other races. This precluded comparison between type of cleft and race, due to the small number of patients of Asian and African descent. Most patients were characterized as belonging to the low socioeconomical bracket (around 70\%).

Table 1 reveals the overall distribution of the several types of clefts.

The combinations of bilateral clefts observed are described in Table 2. Percentages are calculated based on the total number of bilateral clefts.

Graph 1 depicts the distribution of the types of isolated cleft lip.

Graph 2 reveals the distribution of the types of isolated cleft palate.

\section{DISCUSSION}

The most frequent type of cleft was the complete cleft lip and palate, either unilateral or bilateral, which comprised $37.1 \%$ of the sample, followed by isolated cleft palate $(31.7 \%)$ and isolated cleft lip (28.4\%). A small percentage of patients $(1.9 \%)$ presented a number of types of bilateral clefts (Table 1), comprising combinations of cleft lip 
Freitas JAS, Dalben GS, Santamaria Júnior M, Freitas PZ. Current data on the characterization of oral clefts in Brazil. Braz Oral Res 2004;18(2):128-33.

TABLE 1 - Distribution of the several types of clefts.

\begin{tabular}{|c|c|}
\hline \multirow{2}{*}{$\begin{array}{l}\text { Isolated cleft palate } \\
(31.7 \%)\end{array}$} & $\begin{array}{l}\text { Complete cleft palate - } \\
5.2 \%\end{array}$ \\
\hline & $\begin{array}{l}\text { Incomplete cleft palate - } \\
26.5 \%\end{array}$ \\
\hline \multirow{4}{*}{$\begin{array}{l}\text { Isolated cleft lip } \\
(28.4 \%)\end{array}$} & $\begin{array}{l}\text { Complete unilateral cleft } \\
\text { lip }-8.5 \%\end{array}$ \\
\hline & $\begin{array}{l}\text { Incomplete unilateral cleft } \\
\text { lip - } 15.5 \%\end{array}$ \\
\hline & $\begin{array}{l}\text { Complete bilateral cleft } \\
\text { lip }-2.8 \%\end{array}$ \\
\hline & $\begin{array}{l}\text { Incomplete bilateral cleft } \\
\text { lip }-1.6 \%\end{array}$ \\
\hline \multirow{3}{*}{$\begin{array}{l}\text { Complete cleft lip } \\
\text { and palate } \\
(37.1 \%)\end{array}$} & $\begin{array}{l}\text { Left complete cleft lip and } \\
\text { palate }-15.2 \%\end{array}$ \\
\hline & $\begin{array}{l}\text { Right complete cleft lip } \\
\text { and palate }-9.7 \%\end{array}$ \\
\hline & $\begin{array}{l}\text { Bilateral complete cleft lip } \\
\text { and palate }-12.2 \%\end{array}$ \\
\hline \multirow{3}{*}{$\begin{array}{l}\text { Other combinations } \\
\text { of clefts } \\
(3.8 \%)\end{array}$} & $\begin{array}{l}\text { Other combinations of } \\
\text { bilateral clefts }-1.9 \%\end{array}$ \\
\hline & Rare clefts $-1.0 \%$ \\
\hline & Median clefts $-0.9 \%$ \\
\hline
\end{tabular}

TABLE 2 - Distribution of the bilateral clefts.

\begin{tabular}{l|c}
\hline \multicolumn{1}{c|}{ Combinations of bilateral clefts } & Percentages \\
\hline Bilateral complete cleft lip and palate & 71.6 \\
\hline $\begin{array}{l}\text { Bilateral cleft lip (complete or } \\
\text { incomplete) }\end{array}$ & 16.4 \\
\hline $\begin{array}{l}\text { Left complete cleft lip and palate } \\
\text { associated to right cicatricial cleft lip }\end{array}$ & 1.3 \\
\hline $\begin{array}{l}\text { Left complete cleft lip and palate } \\
\text { associated to right incomplete cleft } \\
\text { affecting the lip }\end{array}$ & 6.7 \\
$\begin{array}{l}\text { Left complete cleft lip and palate } \\
\text { associated to right incomplete cleft } \\
\text { affecting the lip and alveolar ridge }\end{array}$ & 0.6 \\
\hline $\begin{array}{l}\text { Left incomplete cleft lip associated to } \\
\text { right cleft lip and palate }\end{array}$ & 2.7 \\
\hline
\end{tabular}

with different degrees of severity at both sides, as well as combinations of incomplete cleft lip at one side and complete cleft lip and palate on the other. These values are in agreement with many other studies in the literature ${ }^{3,6-8,10,11,16,17,19}$, although a few authors have found different results $1,2,15,18$.

The isolated unilateral cleft lip may have different degrees of severity, ranging from a mild cicatricial cleft, incomplete cleft lip affecting just

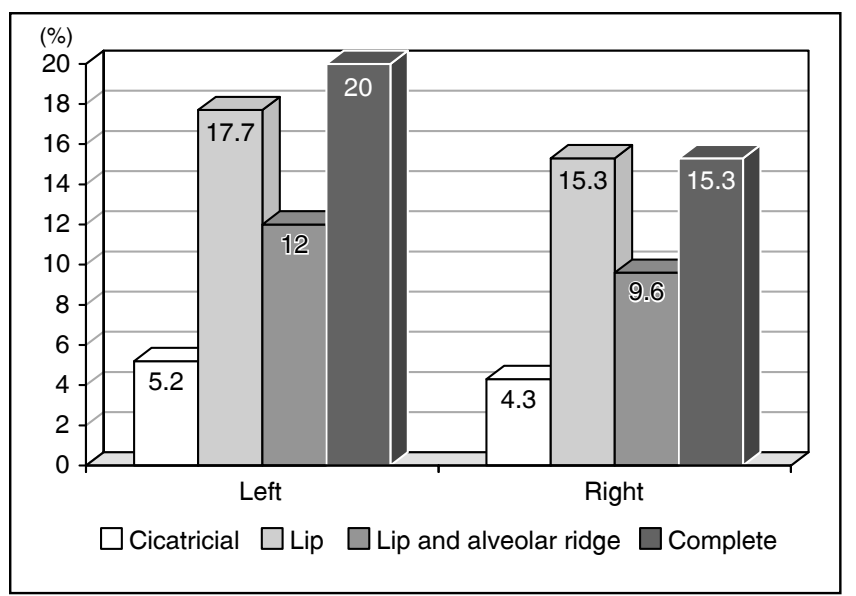

GRAPH 1 - Characterization of isolated cleft lip.

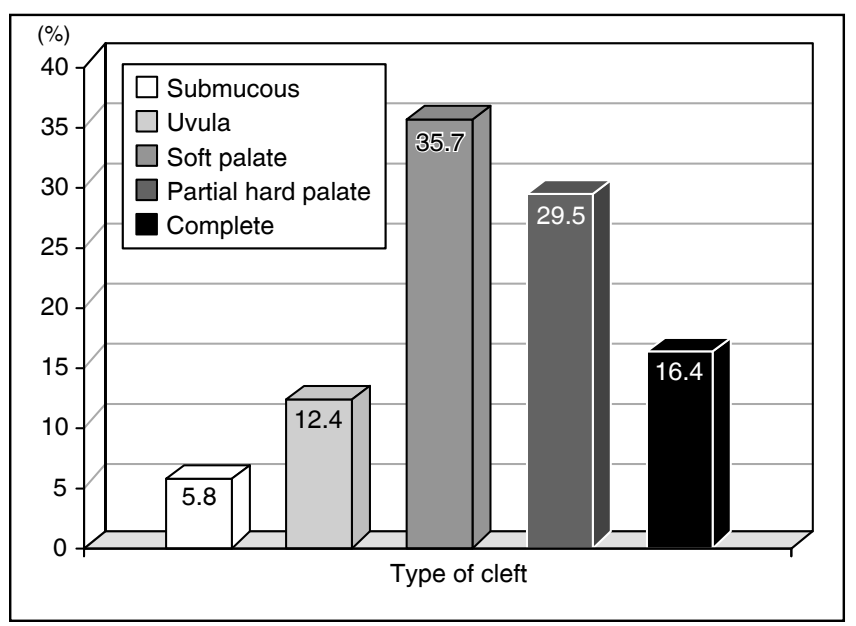

GRAPH 2 - Characterization of isolated cleft palate.

the lip, incomplete cleft lip affecting the lip and alveolar ridge, and finally the complete isolated cleft lip, which affects the lip, alveolar ridge and hard palate up to the incisive foramen. Within the group of patients with isolated unilateral cleft lip, the left side was more affected than the right (Figure 2). Complete cleft lip was the most frequent type of cleft in this group, comprising $20 \%$ of the clefts on the left side and $15.3 \%$ on the right side. The second most frequent type was the incomplete cleft lip involving just the lip, followed by clefts affecting lip and alveolar ridge, and finally the cicatricial clefts, which were quite scarce (Graph 1). No studies were found in the literature describing the extension and severity of cleft lip, which most often is generally regarded as "cleft lip with or without cleft palate". This characteristic makes the establishment of treatment protocols rather difficult, since it does not allow the determina- 

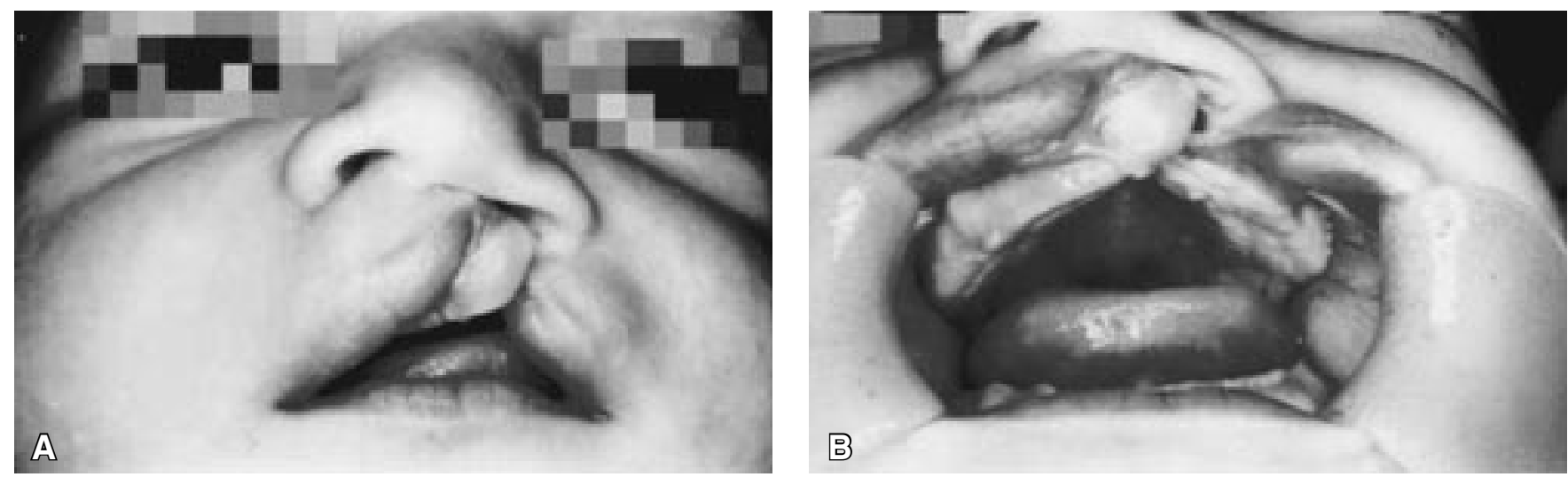

FIGURE 2 - Complete left cleft lip, extraoral (A) and intraoral (B) views.
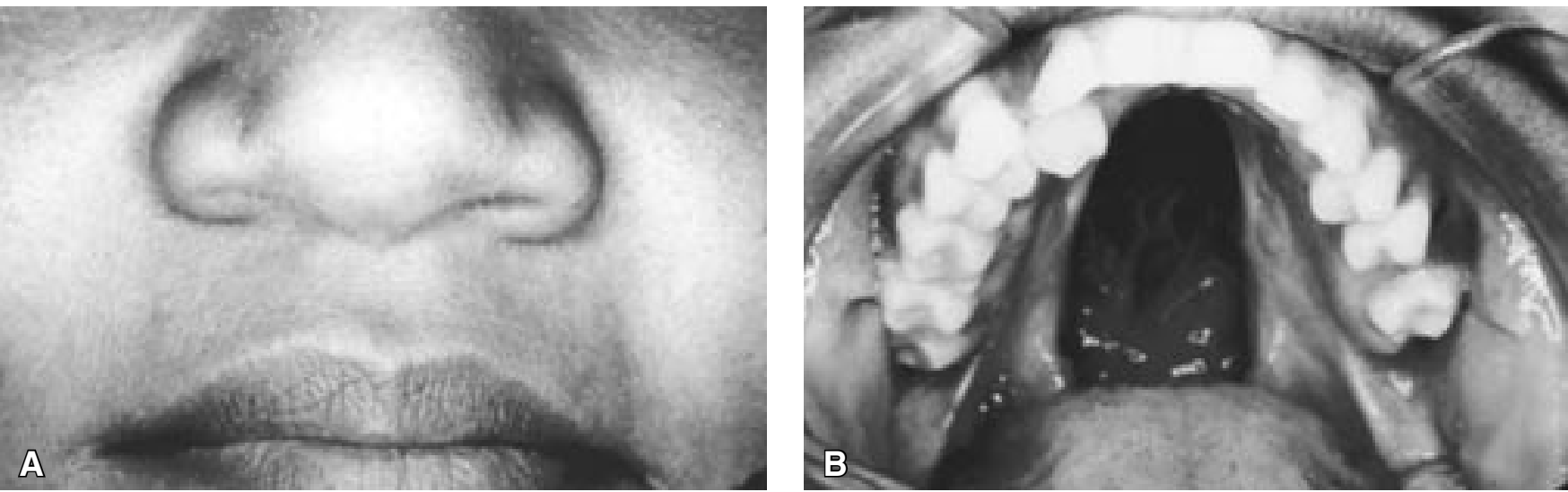

FIGURE 3 - Complete cleft palate, extraoral (A) and intraoral (B) views.

tion of the need for alveolar bone graft through epidemiological data. Nevertheless, most of the sample with cleft lip presented involvement of the alveolar ridge, thus leading to the need for grafting procedures for a proper orthodontic finalization without the limitation imposed by the bone defect or even with a view to prosthetic rehabilitation over osseointegrated implants.

In the group of patients with isolated cleft palate, those clefts affecting just the soft palate were the most frequent, comprising $35.7 \%$ of these patients, followed by clefts involving part of the hard palate $(29.5 \%)$ and complete cleft palate $(16.4 \%)$ (Figure 3) (Graph 2). Similarly to the isolated cleft lip, no studies describing the exact extension of the isolated cleft palate could be found in the literature.

Unilateral clefts of the lip and palate simultaneously and completely involving the primary and secondary palates were more common than the bilateral (66.9\% and $32.9 \%$ respectively). There was a higher rate of clefts at the left side (40.9\%), which was 1.5 times more affected than the right side $(26.0 \%)$. These characteristics were very similar to those observed by many other authors over the years ${ }^{2-4,6,7,9,14-18}$. Few data can be found in the literature to explain this global trend towards clefting at the left side, especially due to the limited knowledge on the etiology of cleft lip and palate. Shapira et al. ${ }^{17}(1999)$ provided one explanation for this, suggesting that the larger blood supply to the right side during the early stages of formation of the embryo, due to the higher blood pressure of the internal carotid artery, might be a likely reason for this feature.

The bilateral clefts presented a broad morphological range, with several possible combinations, most with a low frequency, the most common of which was the bilateral cleft lip and palate (71.6\%) (Table 2) (Figure 4).

Taking into account the possible relationship between gender and type of cleft, the findings also 

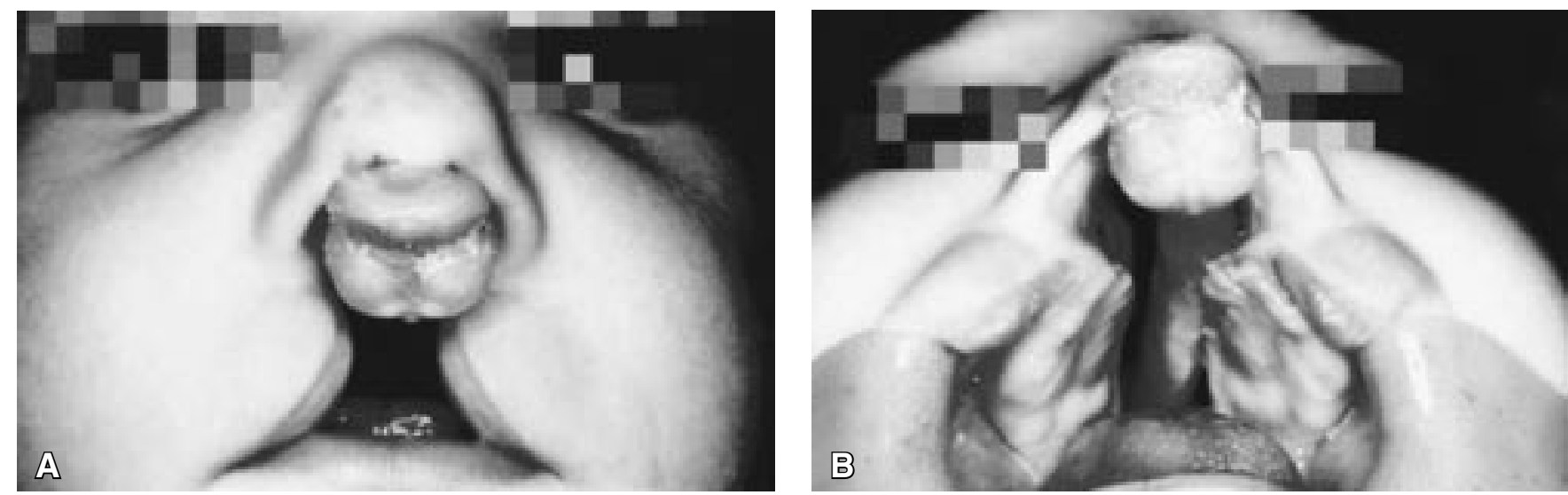

FIGURE 4 - Complete bilateral cleft lip and palate, extraoral (A) and intraoral (B) views.

agreed with those observed in the literature. Despite the small number of subjects in the group of isolated cleft lip, a tendency towards the male gender could be noticed (60\%). The isolated cleft palate was present at a higher rate in female individuals, which constituted $53.2 \%$ of the sample. The complete cleft lip and palate, either unilateral or bilateral, presented a remarkable predominance in the male gender, namely $59 \%$ and $64 \%$, respectively.

\section{REFERENCES}

1. Antoszewski B, Kruk-Jeromin J. Epidemiology of cleft lip and palate in Lodz, Poland, in the years 1981-1995. Acta Chir Plast 1997;39:109-12.

2. Bellis TH, Wohlgemuth B. The incidence of cleft lip and palate deformities in the south-east of Scotland (1971-1990). Br J Orthod 1999;26:121-5.

3. Chuangsuwanich A, Aojanepong C, Muangsombut S, Tongpiew P. Epidemiology of cleft lip and palate in Thailand. Ann Plast Surg 1998;41:7-10.

4. Collares MVM, Westphalen ACA, Costa TCD, Goldim JR. Fissuras lábio-palatinas: incidência e prevalência da patologia no Hospital de Clínicas de Porto Alegre: um estudo de 10 anos. Rev AMRIGS 1995;39:183-8.

5. Cooper ME, Stone RA, Liu Y, Hu D, Melnick M, Marazita ML. Descriptive epidemiology of nonsyndromic cleft lip with or without cleft palate in Shanghai, China, from 1980 to 1989. Cleft Palate Craniofac J 2000;37:274-80.

6. Derijcke A, Eerens A, Carels C. The incidence of oral clefts: a review. Br J Oral Maxillofac Surg 1996;34:488-94.

7. Fonseca EP, Rezende JRV. Incidência das malformações do lábio e do palato. Rev Fac Odontol São Paulo 1971; 9:45-58.

8. Greene JC, Vermilion JR, Hay S, Gibbens SF, Kerschbaum S. Epidemiologic study of cleft lip and cleft palate in four states. J Am Dent Assoc 1964;68:387-404.

\section{CONCLUSIONS}

- The complete cleft lip and palate was more frequent than the other types of clefts, comprising $37.1 \%$ of the total sample, of which $24.9 \%$ were unilateral and $12.2 \%$ bilateral;

- isolated cleft palate comprised $31.7 \%$ and isolated cleft lip $28.4 \%$;

- in general, the clefts were more common among male individuals; isolated cleft palate was the only one in which females were predominant (53.2\%).

9. Ivy RH. Influence of race on incidence of cleft lip and cleft palate. Plast Reconstr Surg 1962;30:581-5.

10. Jensen BL, Kreiborg S, Dahl E, Fogh-Andersen P. Cleft lip and palate in Denmark, 1976-1981: epidemiology, variability, and early somatic development. Cleft Palate J 1988;25:258-69.

11. Kozelj V. Epidemiology of orofacial clefts in Slovenia, 1973-1993: comparison of the incidence in six European countries. J Craniomaxillofac Surg 1996;24:378-82.

12. Menegotto BG, Salzano FM. Epidemiology of oral clefts in a large South American sample. Cleft Palate Craniofac J 1991;28:373-7.

13. Milerad J, Larson O, Hagberg C, Ideberg M. Associated malformations in infants with cleft lip and palate: a prospective, population-based study. Pediatrics 1997;100:1806.

14. Murray JC, Daack-Hirsch S, Buetow KH, Munger R, Espina L, Paglinawan N, et al. Clinical and epidemiological studies of cleft lip and palate in the Philippines. Cleft Palate Craniofac J 1997;34:7-10.

15. Nagem Filho H, Morais N, Rocha RGF. Contribuição para o estudo da prevalência das malformações congênitas labiopalatais na população escolar de Bauru. Rev Fac Odontol Univ São Paulo 1968;6:111-28. 
Freitas JAS, Dalben GS, Santamaria Júnior M, Freitas PZ. Current data on the characterization of oral clefts in Brazil. Braz Oral Res 2004;18(2):128-33.

16. Rajabian $\mathrm{MH}$, Sherkat M. An epidemiologic study of oral clefts in Iran: analysis of 1,669 cases. Cleft Palate Craniofac J 2000;37:191-6.

17. Shapira Y, Lubit E, Kuftinec MM, Borell G. The distribution of clefts of the primary and secondary palates by sex, type and location. Angle Orthod 1999;69:523-8.
18. Stoll C. Associated malformations in cases with oral clefts. Cleft Palate Craniofac J 2000;37:41-7.

19. Tolarová MM, Cervenka J. Classification and birth prevalence of orofacial clefts. Am J Med Genet 1998; $75: 126-37$

Received for publication on Nov 13, 2003

Sent for alterations on Feb 11, 2004

Accepted for publication on Apr 05, 2004 